\title{
Evaluation of the levels of stress in the elderly living at home
}

\author{
Avaliação do índice de estresse em idosos residentes em domicílio \\ Evaluación del nivel de estrés en ancianos residentes en domicilio
}

Juliana Ladeira Garbaccio ${ }^{1}$, Alanna Gomes da Silva², Morgana Michella Barbosa ${ }^{3}$

This study aimed at evaluating the stress level of the elderly assisted by the Primary Health Care of Piumhi, in the Midwest of Minas Gerais, Brazil, in 2010. This was a cross-sectional research with of 64 elderly residents in households. There was a predominance of older women. Regarding chronic diseases $81.3 \%$ were bearers of chronic diseases, $75 \%$ were cardiac and 29.7\% had depression. In the Inventory of Symptoms of Stress for Adults, seniors kept the average 7 (low stress), being more frequent cognitive stress. Female gender was associated with stress level $(p<0.05)$. The elderly showed a good physical and mental status, and we identified low levels of stress, predominantly the cognitive stress type.

Descriptors: Stress, Physiological; Health of the Elderly; Mental Health.

Objetivou-se avaliar o nível de estresse de idosos assistidos pela Atenção Primária à Saúde de Piumhi, Minas Gerais, Brasil, em 2010. Pesquisa transversal com 64 idosos residentes em domicílios. Houve predominância de idosos do sexo feminino. Dentre os analisados, 81,3\% eram portadores de doenças crônicas; destes, 75\% eram cardíacos e 29,7\% apresentaram depressão. No Inventário de Sintomas de Estresse para Adultos, os sujeitos mantiveram a média 7 (estresse baixo), sendo mais frequente o estresse cognitivo. Houve associação $(\mathrm{p}<0,05)$ entre o sexo feminino e o nível de estresse. No geral, os idosos apresentaram bom estado físico e mental, além de ter sido identificado baixo índice de estresse, com predomínio do tipo cognitivo.

Descritores: Estresse Fisiológico; Saúde do Idoso; Saúde Mental.

El objetivo fue evaluar el nivel de estrés de ancianos asistidos por la Atención Primaria de Salud de Piumhi, Minas Gerais, Brasil, en 2010. Estudio transversal con 64 ancianos residentes en domicilio. Hubo predominio de ancianas. De los analizados, 81,3\% eran portadores de enfermedades crónicas; de estos, 75\% eran cardíacos y 29,7\% presentaron depresión. En el Inventario de Síntomas de Estrés para Adultos, los ancianos mantuvieron promedio 7 (baja tensión), siendo el estrés cognitivo más frecuente. Hubo asociación $(\mathrm{p}<0,05)$ entre el sexo femenino y el nivel de estrés. En general, los ancianos presentaron buen estado físico y mental, y se identificó bajo nivel de estrés, con predominio del tipo cognitivo.

Descriptores: Estrés Fisiológico; Salud del Anciano; Salud Mental.

\footnotetext{
${ }^{1}$ Pontifícia Universidade Católica de Minas Gerais. Belo Horizonte, MG, Brazil.

${ }^{2}$ Minasfungi do Brasil. Belo Horizonte, MG, Brazil.

${ }^{3}$ Centro de Atenção Psicossocial de Piumhi-CAPS II, Piumhi, MG, Brazil.
}

Corresponding author: Alanna Gomes da Silva

Rua Alzira Torres, 1.197, Nações, CEP: 38900-000, Bambuí, MG, Brazil. E-mail: alannagomes96@yahoo.com.br 


\section{Introduction}

Until the end of the decade of 1970, Brazil was essentiality a young country, due to the high rates of birth. From the 1980 on, there was a change in the Brazilian demographic profile, with a with gradual increase in the elderly population. The alteration in the population dynamics is clear, unquestionable and irreversible. They constitute the Brazilian reality, which requires from society, managers and health professionals and, of the State, changes of attitudes, perceptions and more financial investments, in order to keep functionality, autonomy, independence and the social participation of the elderly together with the family and the community ${ }^{(1-2)}$.

The process of aging is associated to a higher emotional and physical susceptibility, constituting complex heterogeneous and individualized phenomena in which biological, psychological, social and existent aspects are associated. For that, we must consider age as a loss of biological functions which makes the performance of certain activities difficult, but as a process that has influence in several factors which promote alterations in the way of living ${ }^{(3)}$.

Physical, psychic and social changes, resulting from senescence, can be determinant factors for the incidence of stress in the elderly, and they can interfere in their social insertion, reducing the autonomy and the independence of the subject, which jeopardizes his sociability and his welfare, and they are also determinant factors in the incidence of weariness and depression. Other factors which can contribute in the stress of the elderly are: senility, presence of non transmissible chronic diseases (NTCD), retirement, financial instability, death of his near relatives and changes of social roles ${ }^{(4)}$. These alterations can stimulate the liberation of hormones associated to stress: the glucocorticoids, responsible for unleashing neuro-endocrinous responses and dysfunctional behaviors ${ }^{(5)}$.

The term 'stress' was defined as a set of inspective and general reaction of the body facing persistent stimulus, of adverse nature, which can alter the home- ostatic balance, followed by predictable biochemical, psychological, cognitive and behavioral changes related to the alteration of a fact or stressing occurrence ${ }^{(6)}$.

Taking into consideration the fact that stress is considered a forerunner of several diseases which have not receive attention in the studies with the elderly in Brazil, so the following guiding question emerged: what is the level of stress in the elderly living at home?

This research is justified by considering that the factors of stress in the elderly must be investigated, analyzed and understood once the stress influences the occupational, social and familiar life and also the context of health/disease of the elderly. So, this study is aimed at evaluating the level of stress assisted by the Primary Attention to Health in the county of Piumhi, in the Mid-West of Minas Gerais.

\section{Method}

This is a cross-sectional study, with quantitative approach, made in a Basic Health Unit (BHU), chosen at random among the ten units that formed the Primary Attention to Health (PAH) of the county of Piumhi, in the Mid-West of Minas Gerais. The city has approximately 33 thousand inhabitants, $407 \mathrm{~km}$ away from the Minas Gerais capital. This UBS was formed by seven micro areas, having a total of 447 elderly registered in the period of the data collection and the sixth micro area was chosen, which had the largest number of elderly $(77 ; 18 \%)$.

64 elderly registered were evaluated at BHU. The criteria of inclusion of the subjects in the research were: be at least 60 years old, registered at the BHU and have cognitive-functional autonomy allowing him to answer the questions of the research himself.

In the data collection made in August and September, 2010, a form made for the research was used, made up by the social demographic data: gender, age, schooling, marital status, housing, religion, practice of physical activities, use of medicine, non transmissible chronic diseases (NTCD) and the use of tobacco. The Inventory of Symptoms of Stress for Adults (ISSA) val- 
idated by Lipp and Guevara, in 1994, and standardized by Lipp, in 2000. This instrument was based on a three phases model developed by Selye, in 1965. It is aimed at identifying the symptomatology which the subject presents, evaluating if he has symptoms of stress, the type of symptom predominant and the phase which he is in. It is made up by 53 items, being 34 physical items and 19 psychological ones, divided in three quarters: the first chart shows the symptoms experienced in the last 24 hours (twelve physical symptoms and three psychological ones) and the second chart the symptoms of the last week (ten physical symptoms and five psychological ones) and the third chart the symptoms presented in the last month (twelve physical symptoms and eleven psychological ones).

They are divided in three parts, in which the first one emphasizes the existence of stress or not, the second one investigates the stage of the stress in which the subject is (alert, resistance, almost exhaustion or exhaustion) and the third one shows which area of higher manifestation of physical and/or psychological symptoms is ${ }^{(7)}$. The form with the socio-demographic data was applied through interviews, by a nursing student, dully trained and the ISSA by a psychologist.

The data were analyzed in the Statistical package for the social sciences (13.0) program. For the characterization of the population studied, the descriptive statistics was used, made through the calculation of the absolute frequencies and percentages of the socio-demographic variables, presence of non transmissible chronic diseases and the inventory of symptoms of stress. The association between the socio-demographic variables and the inventory of symptoms of stress was verified by the bivariate analysis with the Chi-Squared test of Person, adopting the level of significance of 0.05 .

There was a previous contact with health professional responsible for the BHU, explaining the objectives and the methodology of the research, and a letter of acceptance was signed. The elderly participants in the research also signed the Informed Consent Form. The data collection was made up in the micro area six of a BHU in the city of Piumhi-MG and the use of the instruments occurred in the elderly homes. The research was approved by the Committee of Ethics in Research of the Pontifícia Universidade Católica de Minas Gerais (CAAE - 0048.0.213.000-10).

\section{Results}

64 elderly (83.8\%) from micro area of a BHU of Piumhi were evaluated. The socio-demographic data of the 64 elderly evaluated presented: predominance of women; age between 60 and 79 years; schooling grade school and high school; widow/er, catholic; absence of use of antidepressant medicine; absence of regular physical activity; non smoker.

Regarding the NTCD, $81.3 \%$ of the elderly had cardiac problems. Depression was reported by $29.7 \%$ of them.

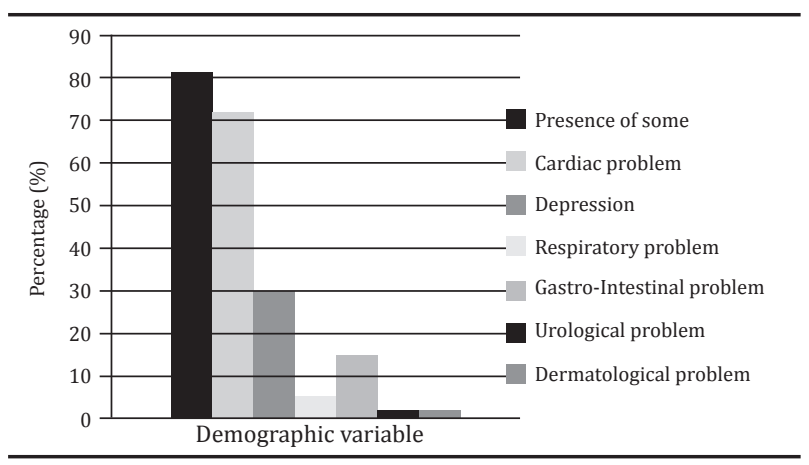

Figure 1 - Presence of non transmissible chronic diseases in the elderly of a Basic Health Unit

In the evaluation of the level of stress of Lipp, the elderly present a high rate of cognitive stress, low rate for somatic stress which varied from 7 (low stress) to 35 (high stress), with low anxiety for 54(84.3\%) of them (Table 1).

Table 1 - Evaluation by the Inventory of Symptoms of Stress for Adults, in elderly of a Basic Unit of Health $(\mathrm{n}=64)$

\begin{tabular}{lc}
\hline Level of Stress & n (\%) \\
\hline Low stress (alert) & $54(84.3)$ \\
Moderate stress (resistance) & $4(6.3)$ \\
High stress (exhaustion) & $6(9.4)$ \\
\hline
\end{tabular}


In the evaluation of associations of the socio-demographic data (age, gender, schooling, marital status, religion, physical activity, use of antidepressants, presence of NTCD and tobacco addiction) with the inventory of stress, there was an association between the female sex and the level of stress $(\mathrm{p}<0.05)$ (Table 2).

Table 2 - Associations between the socio-demographic data and the Inventory of Symptoms of Stress for Adult of a Basic Health Unit ( $\mathrm{n}=64)$

\begin{tabular}{|c|c|c|c|c|c|c|}
\hline \multirow[b]{2}{*}{ Variables } & \multicolumn{6}{|c|}{ Levels of the Inventory of Symptoms of Stress } \\
\hline & n (\%) & $\begin{array}{c}\text { Low } \\
(n=54)\end{array}$ & $\begin{array}{l}\text { Moderate } \\
\qquad(n=4)\end{array}$ & $\begin{array}{l}\text { High } \\
(n=6)\end{array}$ & $\begin{array}{c}\text { Chi- } \\
\text { squared } \\
\text { test }\end{array}$ & $P$ value \\
\hline \multicolumn{7}{|l|}{ Age (years) } \\
\hline $60-69$ & $48(75.0)$ & 20 & 2 & 4 & & \\
\hline $70-79$ & $16(25.0)$ & 24 & 1 & 1 & & \\
\hline$\geq 80$ & $26(40.6)$ & 10 & 1 & 1 & & \\
\hline Gender & & & & & 7.3 & 0.02 \\
\hline Female & $26(40.6)$ & 41 & 1 & 6 & & \\
\hline Male & $12(18.8)$ & 13 & 3 & 0 & & \\
\hline Schooling & & & & & 10.8 & 0.09 \\
\hline Illiterate & $21(32.8)$ & 18 & 2 & 1 & & \\
\hline Grade School & $41(64.1)$ & 35 & 2 & 5 & & \\
\hline High School & $1(1.5)$ & 0 & 0 & 0 & & \\
\hline $\begin{array}{l}\text { University } \\
\text { degree }\end{array}$ & $1(1.5)$ & 1 & 0 & 0 & & \\
\hline Marital Status & & & & & 5.7 & 0.40 \\
\hline Widow (er) & $33(51.6)$ & 28 & 2 & 3 & & \\
\hline $\begin{array}{l}\text { Married or } \\
\text { cohabiting }\end{array}$ & $22(34.4)$ & 20 & 1 & 1 & & \\
\hline Single & $7(10.9)$ & 5 & 1 & 1 & & \\
\hline Divorced & $2(3.1)$ & 1 & 0 & 1 & & \\
\hline Religion & & & & & 0.6 & 0.70 \\
\hline Catholic & 57 (89.1) & 48 & 4 & 5 & & \\
\hline Evangelic & $7(10.9)$ & 6 & 0 & 1 & & \\
\hline \multicolumn{2}{|c|}{ Regular physical activity } & & & & 0.8 & 0.60 \\
\hline No & $43(67.2)$ & 37 & 3 & 3 & & \\
\hline Yes & $21(32.8)$ & 17 & 1 & 3 & & \\
\hline \multicolumn{2}{|c|}{ Use of Antidepressants } & & & & 2.8 & 0.20 \\
\hline No & $45(70.3)$ & 38 & 4 & 3 & & \\
\hline Yes & 19 (29.7) & 16 & 0 & 3 & & \\
\hline \multicolumn{2}{|c|}{ Presence of diseases } & & & & 2.7 & 0.20 \\
\hline No & $12(18.7)$ & 12 & 0 & 0 & & \\
\hline Yes & $52(81.3)$ & 42 & 4 & 6 & & \\
\hline Use of tobacco & & & & & 1.3 & 0.50 \\
\hline No & $50(78.1)$ & 41 & 4 & 5 & & \\
\hline Yes & $14(21.9)$ & 13 & 0 & 1 & & \\
\hline
\end{tabular}

Besides the use of antidepressants, other types of medicine were used by the elderly, such as anti-hypertensive (42.7\%) and oral hypoglycemic (4.5\%).

\section{Discussion}

In this research there was a predominance of the female sex $(66 ; 75 \%)$, mentioned in another epidemiological study which showed that there are 3.9 million more women than men in Brazil. This situation is due to the higher male mortality and because the increase of life expectancy of men is lower, when compared to the female sex. Among the aggravating factors for this occurrence is the smaller presence of man in the service PAH compared to the women, which can be explained by the historicity of masculinity and for cultural matters ${ }^{(8)}$.

The average age of the elderly was from 60 to 79 years (81.2\%); such scenario may be a reflex of the demographical transition, in which there is an increase of life expectancy worldwide recognized. The population of Brazilian elderly doubled and this growth occurred strongly, due to the current life expectancy (74 years). It is estimated that, in the year 2025, Brazil will have the sixth largest population of elderly in the world ${ }^{(9)}$.

As to schooling, it was observed that most of them had grade school (65.6\%) or was illiterate (32.8\%), which can be justified by the situation experienced by the elderly at a time in which teaching in Brazil was not a priority, once the opportunity of studying was offered only for the upper social classes. Low schooling limits the understanding, reduces the access to information, the capacity of reading and writing, reduces the chance to have a good professional carrier and is one of the main factors of social exclu$\operatorname{sion}^{(10)}$.

There was a predominance of widow/ers. The variable marital status has relevance in the existential and psychosocial domain, once it contributes for the evaluation of the conditions of life, when considering the meanings of marriage, widowhood, separations 
and divorces. The widowhood occurs more in the female sex, once the women have a higher life expectancy regarding men and also it is uncommon the marriage with people older than 60 years; however, men have more possibility to marry again than the women $^{(11)}$.

Concerning religion there was a predominance of catholic. It is relevant for the health of the elderly to have some religion, independently of the religiosity they practice or follow religiosity, once the religious involvement contributes for the promotion and maintenance of the welfare and the Quality of Life, acting both as an emotional support which has a positive repercussion in the physic, psychic and social health ${ }^{(12)}$.

It is highlighted that $70.3 \%$ of the elderly mentioned not taking antidepressant. On the other hand, it is known that many elderly do not know the medicine they take, so it is possible that some of them take antidepressants, but did not report during the research. Concerning the medicine in elderly, especially the psychotropic, the administration deserves attention, once the elderly is more vulnerable to side effects and, therefore, many medicines are considered inappropriate. The doctor, when prescribing these medicines for the elderly, must consider the adequate ones, the dosage, time of treatment, its efficacy and side effects ${ }^{(13)}$.

Of the investigated elderly $67.2 \%$ reported to be sedentary, which has a negative repercussion in health. Among the available strategies for the control of stress, the practice of physical activities has been outstanding as an accessible and effective option. A study with several populations suggest that the level of stress in the physically active ones is inferior to the sedentary ones. The performance of physical activities provides physical and psychological benefits, improves the quality of life and the self image, making the person feel healthy ${ }^{(14)}$.

A few elderly reported to be smokers (21.9\%), which was a satisfactory result. The smokers look for immediate pleasure or to relieve unpleasant emotional symptoms, such as anxiety, wrath, depression and stress. Among the smokers, the symptom of the stress is suggested in higher levels than the people do not smoke. The tobacco is directly associated to the stress in daily life, once the smokers present higher level of stress than the non smokers ${ }^{(15)}$.

Among the 64 elderly, $81.3 \%$ were bearers of some kind of NTCD and 75\% presented cardiac problems. Aging is a dynamic process, in which modifications from the molecular to the morphophysiological level happen, inducing to organic decline, increasing the susceptibility and diseases. The elderly are more vulnerable to degenerative diseases of insidious start, as cardiovascular, cerebrovascular, cancers, mental disorders and diseases which attack the locomotor sensorial system. The cardiovascular disease is the highest cause of mortality and morbidity in Brazil, due to the alterations in the cardiovascular system, such as arteriosclerosis, decrease of the distensibility of the aorta and of the longest arteries, jeopardizing of the cardiac function and reduction of the baroreceptors function. A situation which is aggravated when the subject did not have along his existence, healthy habits of life. Besides the cardiovascular problems, the following diseases have a high incidence in the elderly: hypertension, diabetes and neoplasias; dementia (especially Alzheimer's disease); depression and osteoporosis ${ }^{(16-17)}$.

Through the use of the ISSA, it was observed that the elderly in this research had a low punctuation concerning the symptoms related to stress, reporting that never or rarely did they feel it. In the classification as to the type of stress, there was a higher rate of cognitive stress and a low rate of somatic stress; the final score was 7 for most (the lowest punctuation of the test) showing a low level of stress.

Stress can present itself through symptoms called cognitive and somatic. Several somatic reactions occur in the human blood facing stressing agents, such as muscular tension, tachycardia, tachypnea, increase of the sudoresis, alteration of the appetite, nausea, insomnia, excitement, headache, increase of the diuresis, thoracic discomfort, among others. Regarding 
cognitive effects, the subject presents symptoms like anxiety, tension, anguish, interpersonal difficulties, low esteem, wrath, excessive worrying and emotional hyper sensibility ${ }^{(5-18)}$.

The method used, through the use of the ISSA is based on the physical and psychological symptoms and, according to the symptoms shown, the patient can be in one of these stages: alarm (light), resistance (moderate) or exhaustion (high). The classification of the stages of stress is necessary to know the sequence in which the body reacts to the activity in his environment $^{(19)}$.

Concerning the stages of stress, at first, comes the stage of alarm, in which the subject shows several sensations, which sometimes are not identified as stress, such as paleness, tachycardia and tachypnea, among others, which are linked to the instinct of survival. The second stage is the resistance stage, in which the organism will try to return to a condition balance, and if it is retaken, some initial symptoms will disappear, occurring the Local Adaptation Syndrome (LAS). In this stage, there is the manifestation of psychosocial symptoms such as anxiety, fear, social isolation, change of appetite and others. The third stage, exhaustion, is defined by the incapacity of the body to return to balance and can be shown as organic diseases $^{(19)}$.

As to the level of stress in this study, the most frequent was the stage of alert (84.3\%), followed by the stage of exhaustion (9.4\%). Due to these results, strategies must be promoted in order to prevent the evolution to the other stages, avoiding harmful consequences to health. So, it is necessary to be aware to stressing events, which trigger adaptive reactions, being possible to confront them. This confrontation must have the focus on the problem, modifying itself concerning the person with the environment, in order to adequate the emotional reaction. The social support and the religiosity can also be used as means to deal with the stressing event ${ }^{(20)}$.

The results showed a significant correlation between gender and the level of stress $(p<0.05)$, where the women presented the higher level. Along the years there have been changes of paradigms current in the Brazilian culture, related to the role of women in society. Before it was believed that men had a higher level of stress than the women because they are the family maintainers. However, with the change of the woman in society, the level of female stress has increased, due to their higher participation in the work market, besides the household's chores, taking care of the children, of the spouse and other family members. There are also biological factors of the female sex which cause a higher predisposition to stress to women and which are related to the hormonal cycles. Biological factors, together with the social ones can explain the higher levels of stress in women when compared to men, however, these data cannot effectively prove that the women are more stressed than men ${ }^{(21)}$.

The use of antihypertensive and oral hypoglycemic in the elderly participants of the study is justified by the increase of NTCD, among them high blood pressure and diabetes mellitus ${ }^{(22)}$.

The actions to improve the quality of life and health of the elderly, as well as the care for prevention, identification and treatment of the stress and its other necessities, whether physiological, emotional, social or spiritual, can be taken by the nurse who works at the PAH and this health professional must know the elderly totally and particularly. The nurse and his team must know how to interfere facing the problems which affect the elderly and so provide a kind of care based on recovery, maintenance and promotion of the autonomy and independence through the development of individual and collective health actions, keeping the elderly in the community, together with his family, in a dignifying and comfortable manner ${ }^{(23)}$.

\section{Conclusion}

Physical, psychic or social changes experienced by the elderly can be resultant from the aging process and can be considered a threat to his biopsychosocial maintenance, constituting stressing factors, able to 
stimulate behavioral and neuro-endocrinal responses in the attempt of adaptation to the stressing events.

Facing the evaluation developed, this study made possible to emphasize the level of stress of the elderly assisted by the Attention to Primary Health. Considering the risks to health that the stress can cause in the life of elderly and especially by the fact of the increase of life expectancy of the population. The nursing professional being responsible for the health can developed action, programs and researches in an innovative manner and plainly justified which have as focus the evaluation and identification of the variables which may interfere direct or indirectly in the process of aging, as well as in their relation with stress and other biopsychosocial changes. So, the actions and researches of nursing, in context of the stress in the health of the elderly are relevant and valid.

There are few publishings on the evaluation of stress in elderly at home determining a perceptible gap in the knowledge and, for this reason, it is necessary more attention on this thematic, like the development of studies which illustrate the identification of the stressing agents, as well as the level of stress of these elderly. Especially for being directly related to the health condition and quality of life. Another limiting point consists in the small number of elderly interviewed. Furthermore, it is important the making of researches with a larger sample made in big urban centers and in the Long Stay Institutions for the Elderly, bringing more data on the thematic.

The elderly presented, in general, a good physical and mental condition. A low level of stress in the elderly participants in the research was identified. The elderly of the sample do not show the symptoms evaluated by the inventory or reported rare occurrence, which made most of them receive a score of 7 points. When comparing the levels of stress through which the elderly were attacked, there was a prevalence of the cognitive type.

It is expected that this research bring contributions on the data and obtain more information on the stress of the elderly living at home. From the results it is expected to have a closer approximation with this reality of such importance in the scope of public health, aiming at promoting more knowledge to the health professionals so that they can identify the stressing agents and so, propose measures of confrontation to help getting a better quality of life for the elderly who live at home.

\section{Collaborations}

Garbaccio JL contributed for the orientation of the research, for the conception of the work, analysis and interpretation of the data, writing of the article and final approval of the version to be published. Silva AG contributed for the conception of the work, interpretation of the data, writing of the article and final approval of the version to be published. Barbosa MM contributed for the conception of the work and data collection.

\section{References}

1. Küchemann BA. Envelhecimento populacional, cuidado e cidadania: velhos dilemas e novos desafios. Soc Estado. 2012; 27(1):165-80.

2. Clares GWB, Freitas MC, Almeida PC, Galiza FT, Queiroz TA. Perfil de idosos cadastrados numa unidade básica de saúde da família de FortalezaCE. Rev Rene. 2011; 12(4):988-94.

3. Lima AMM, Silva HS, Galhardoni R. Envelhecimento bem-sucedido: trajetórias de um constructo e novas fronteiras. Interface. 2009; 12(27):795807.

4. Melo RLP, Eulálio MC, Gouveia VV, Silva, HDM. O efeito do estresse na qualidade de vida de idosos: o papel moderador do sentido de vida. Psicol Reflex Crit. 2013; 26(2):222-30.

5. Souza-Talarico JN, Caramelli P, Nitrini R, Chaves EC. Sintomas de estresse e estratégias de coping em idosos saudáveis. Rev Esc Enferm USP.2009; 43(4):803-9.

6. Borges CS, Luiz AMG, Domingos NAM. Intervenção cognitivo-comportamental em estresse e dor crônica. Arq Ciênc Saúde. 2009; 16(4):181-6. 
7. Lipp MEN. Manual do inventário de sintomas de stresse para adultos de Lipp (ISSL). São Paulo: Casa do Psicólogo; 2000.

8. Instituto Brasileiro de Geografia e Estatística (IBGE). Sala de Imprensa: Pesquisa nacional por amostra de domicílios [Internet]. 2009 [citado 2012 dez 05]. Disponível em: http://www.ibge.gov.br/home/estatistica/ populacao/trabalhoerendimento/pnad2009/ default.shtm?utm_medium=twitter\&utm source $=$ twitterfeed

9. Belon AP, Barros MBA. Esperança de vida ao nascer: impacto das variações na mortalidade por idade e causas de morte no Município de Campinas, São Paulo, Brasil. Cad Saúde Pública. 2011; 27(5):877-87.

10. Geib LTC. Determinantes sociais da saúde do idoso. Ciênc Saúde Coletiva. 2012; 17(1):123-33.

11. Oliveira BLCAO, Silva AM, Baima VJ, Barros MMP, Cruz MSBV, Cunha CLF. Situação social e de saúde da população idosa da uma comunidade de São Luís-MA. Rev Pesq Saúde.2010; 11(3):25-9.

12. Cardoso MCS, Ferreira MC. Envolvimento religioso e bem-estar subjetivo em idosos. Psicol Ciênc Prof. 2009; 29(2):380-93.

13. Noia AS, Secoli SR, Duarte YAO, Lebrão ML, Lieber NSR. Factors associated to the use of psychotropc drugs by community-dwellingelderly in São Paulo City. Rev Esc Enferm USP. 2012; 46(n. esp):38-43.

14. Viana MS, Andrade A, Back AR, Vasconcellos DIC. Nível de atividade física, estresse e saúde em bancários. Motri. 2010; 6(1):19-32.

15. Cardoso BAP, Santos MLC, Berardinelli LMM. A relação estilo de vida e tabagismo entra acadêmicos de enfermagem. Rev Eletr Enf. [periódico na Internet] 2009; 11(2):368-74. Disponível em: http://www.fen.ufg.br/revista/ v11/n2/v11n2a18.htm
16. Virtuoso JF, Balbé GP, Mazo GZ, Pereira MGS, Santos FSS. Morbidade e mortalidade da população idosa de Florianópolis: um estudo comparativo entre homens e mulheres. Rev Bras Geriatr Gerontol. 2010; 13(2):215-24.

17. Machado JC, Ribeiro RCL, Cotta RMM, Leal PFG. Declínio cognitivo de idosos e sua associação com fatores epidemiológicos em Viçosa, Minas Gerais. Rev Bras Geriatr Gerontol. 2011; 14(1):109-22.

18. Santos AT, Leyendecker DD, Costa ALS, SouzaTalarico JN. Subjective memory complain in healthy elderly: influence of depressive symptoms, perceived stress and self-esteem. Rev Esc Enferm USP. 2012; 46(n.spe):24-9.

19. Almeida NDV. Considerações acerca da incidência de estresse em motoristas profissionais. Rev Psicol UFC [periódico na Internet]. 2010 [citado 2014 mar 24]; 1(1):75-84. Disponível em: http:// www.revistapsicologia.ufc.br/images/pdf/ ano1edicao1/ano1edicao1006.pdf

20. Duarte FM, Wanderley KS. Religião e espiritualidade de idosos internados em uma enfermaria geriátrica. Psicol Teor Pesq. 2011; 27(1):49-53.

21. Wottrich SH, Ávila CM, Machado CC, Goldmeier S, Dillenburg D, Kuhl CP, et al. Gênero e manifestação de stress em hipertensos. Estud Psicol. 2011; 28(1):27-34.

22. Gontijo MF, Ribeiro AQ, Klein $\mathrm{CH}$, Rozenfeld $\mathrm{S}$, Acurcio FA. Uso de anti-hipertensivos e antidiabéticos por idosos: inquérito em Belo Horizonte, Minas Gerais, Brasil. Cad Saúde Pública. 2012; 20(7):1337-46.

23. Pilger C, Dias JF, Kanawava C, Baratieri T, Carreira L. Compreensão sobre o envelhecimento e ações desenvolvidas pelo enfermeiro na atenção primária à saúde. Ciênc Enferm. 2013; 19(1):6173. 